\title{
BIOLOGY TEACHERS' CONCEPTIONS ABOUT THE ORIGIN OF LIFE IN BRAZIL, ARGENTINA, AND URUGUAY: A COMPARATIVE STUDY
}

\author{
by Heslley Machado Silva, Pierre Clément, \\ Isabela Maria Silva Leão, Tiago Valentim Garros, \\ and Graça Simóes Carvalho
}

\begin{abstract}
Teachers' conceptions about the origin of life in three Latin American countries with contrasting levels of secularism were analyzed: Argentina (Catholic constitution), Brazil (formally secular but not in practice), and Uruguay (consolidated secularism). A European survey questionnaire was used and the interpretation of the results drew on Barbour's four categories concerning the relationships of science and religion. A large majority of Argentinian and Uruguayan teachers were clearly evolutionist, even when believing in God (Independence or Dialogue category), with no difference between Argentina and Uruguay. The majority of Brazilian teachers assumed a religious position about the origin of life, being creationist (Conflict or Independence categories) or evolutionary creationist (Dialogue or Integration categories). Differences of Brazilian teachers' conceptions may result from the higher percentage of evangelicals and lower proportion of agnostics/atheists. Brazilian Catholic teachers were more creationist than their Catholic colleagues in Argentina and Uruguay. Distinct patterns were found, but further research is needed to understand possible classroom impacts.
\end{abstract}

Keywords: beliefs; creationism; evolution; Latin America; origin of life; school teachers

Heslley Machado Silva is Professor and Researcher at the Formiga University Center, MG, Brazil; e-mail: heslley@uniformg.edu.br. Pierre Clément is Invited Retired Professor at the Aix-Marseille Université, Marseille-ADEF, France; e-mail clement.grave@free.fr. Isabela Maria Silva Leão is a student and researcher at the Formiga University Center, MG, Brazil; e-mail isabela.leao94@hotmail.com. Tiago Valentim Garros is a PhD Candidate in the Theology, Faculdades EST, São Leopoldo-RS, Brazil; e-mail tiagogarros@gmail.com. Graça Simôes Carvalho is Full Professor and Head of the Research Center on Child Studies at the University of Minho, Braga, Portugal; e-mail graca@ie.uminho.pt. 
Biology Teachers Face to Face with Science and Religion

Perceptions of the relationship between science and religion are often polarized. Although sometimes thought to be exclusive to the United States, such perceptions have global reach, and Latin American countries see this notion of conflict all too often. This notion of conflict between the interests and findings of science on the one hand and religious views on the other is most clearly seen when it comes to the questions concerning the origin of life. Creationism and denial of evolution have been gaining momentum in Latin America, accompanying an unprecedented growth of evangelical churches over the last thirty years, mostly from the Pentecostal or neo-Pentecostal strands. In Brazil, for example, evangelicals, only 6.6 percent of the population in 1980 , grew to 22.2 percent in 2010 , with predictions of representing more than 50 percent of the country's population by 2020 (Fernandes 2009). This growth has led to greater political representation in the parliament, and the evangelical front has been able to push, among other conservative legislation, a creationist bill, much like the familiar North American story. Congressman Marco Feliciano, a well-known evangelical pastor, submitted a proposal ${ }^{1}$ in 2014 for the inclusion of creationism in public and private schools in Brazil, and the bill is still being weighed in the House of Representatives.

Teachers, particularly biology teachers, are, therefore, at the forefront of this clash between religion and science, especially when required to teach themes such as the origin of life and biological evolution (Rodrigues and Mota 2011). They have to face not only their students' perceptions on the matter, but also their own views, opinions, and assessment on the science of origins and how it relates to their own faith or lack thereof. This article, then, aims at presenting the results of a study that analyzed the conceptions of high school (or secondary school) biology teachers in three different Latin American countries with regard to the question of the origin of life.

We are all aware of the multiple attempts to map out the possibilities of the relationship of religion and science. John Hedley Brooke (1991) and Peter Harrison (2015) have shown that religion and science have complex histories, and that the words themselves haven't always meant what they mean today. For a good part of history, they were part of the same endeavor, but in the nineteenth century a major divide seems to have taken place. Popularization of the conflict thesis followed this split, telling a story of an irreconcilable divide between the fields.

Even though the conflict thesis has been widely-and rightfullydiscredited, its myths have been prevalent in mainstream media worldwide, Latin America included. The rise of militant neo-atheism has left marks in Latin America, where the books that topped the bestseller lists in the United States and Europe also sold in great numbers. David Noel 
Livingstone (2010) reminds us of the importance of considering the geography of scientific knowledge (the "geography of reading" in his terms) which begs the question: Does the notion of conflict in Latin American countries play out in the same way it does in North America and Europe, especially with regard to the "Darwinism and God" debate? According to Livingstone, scientific theories have been built and worked out differently in different places and cultures, carrying great influence from the places where they were elaborated. For instance, the scientific communities of Russia, North America, and New Zealand have interpreted evolutionary theory from within their local cultural contexts. Therefore, it would be expected that teachers from different countries elaborate their scientific knowledge about the question of origins with a regional perspective, and the different church-state relationships that each country exhibits may provide interesting insights as to the extent of the effect of national policies about religion and the state.

The three countries we investigated in this study are Argentina, Uruguay, and Brazil. They all exhibit distinct forms of secularism in their churchstate policies and in their sociopolitical makeups. Argentina has an openly Catholic constitution that requires the government to support Roman Catholicism economically. This condition has produced a historical symbiosis in culture, economy, and politics between the Catholic Church and the Argentinian government, with very complex and intricate relations unfolding (Esquivel 2003). On the other hand, Brazil and Uruguay are formally secular states when it comes to their constitutions, but Brazil is indeed only formally secular, with numerous Catholic holidays being observed and the Catholic Church still having great power and influence. In fact, Brazil is still the number one Catholic country in the world in practical terms, considering the number of people who declare themselves to be Catholic (61 percent according to Censo, IBGE, 2010). Besides, as we mentioned, evangelicals have a growing influence and impact on society, as can be seen from the aforementioned creationist bill. The political power of evangelicals and other conservative Christian groups can also be gauged by the influential lobby to boycott any debate in the Brazilian Congress on abortion, homosexual marriage and other topics considered progressive. This partly explains the prominent role played by candidates' religious positions during the last presidential election in 2014. Uruguay, on the contrary, displays a consolidated secularism, where religion plays very little role in political affairs (Oro 2008). This process of laicism in Uruguay has played out very differently when compared to other Latin American countries. It has its roots in the nineteenth century, leading to the total separation of church and state in the 1919 constitution (Kátia Silva and Fontenele 2007). Thus, Uruguayan society today is much more open to accepting ideas like same-sex marriage, abortion, and marijuana liberalization (which in fact has recently taken place), subjects that any 
other country in Latin America still finds hard to even discuss in political circles.

Some empirical data obtained from past research help to shed light in how the overall public perceives the relationship between science and religion when it comes to Darwin and the origin of life. According to a 2005 poll, one-third of Brazilians believe God created humans in their present form less than 10,000 years ago, and 89 percent of the population believes creationism must be taught in schools; 79 percent even say that it should replace evolution (Brum 2005). More recently, in 2010, another poll presented different numbers, showing a friendlier environment: 25 percent of the population believe God created humans in their present form less than 10,000 years ago, with 59 percent believing in an evolution guided by God, and only 8 percent believing in a godless evolutionary process (Datafolha Instituto de Pesquisas 2010). In Argentina, another poll conducted by the British Council has shown that 68 percent of the people think evolution should be taught alongside creationism (BBC News 2009).

An interesting finding from these data is that a significant number of people do not see a necessary conflict between the religious narrative and the scientific one. They are more or less able to move past the conflict thesis towards more constructive approaches, claiming that God could have guided the evolutionary process in some way and could have used natural processes. In order to make sense of these data, we decided to make use of Ian Barbour's famous fourfold typology to relate science and religion: Conflict, Independence, Dialogue, and Integration (Barbour 1990, 2000, 2004; page numbers hereafter follow the 2004 Portuguese translation), and to see how this typology can be applied to the perspectives of high school biology teachers in these three Latin American countries. We shall briefly analyze how we see these categories, as summarized by Tiago Garros (2014a).

Those who see religion and science as conflicting when it comes to the question of origins assert that people must make a choice between the religious narrative, often stemming from a literal reading of the early chapters of Genesis, and the scientific narrative-evolution. In Barbour's words, "scientific materialism and biblical literalism both claim that science and religion make rival literal statements about the same domain (the history of nature), so a person must choose between them" (Barbour $2004,23)$. The representatives of such a view are usually, according to Barbour, scientific materialists on the one hand and, on the other, Christian fundamentalists, adherents to what is commonly known as creationism in its multiple forms (Engler 2007; Garros 2014b). The former group believes the only reliable path to knowledge is the scientific method; because material reality is all there is, science reveals the ultimate truths about reality, and religion should be rejected as ancient superstition. On the other hand, 
biblical literalists read science into the Bible, claiming it offers a somewhat scientific account of the history of our planet, and if "secular science" contradicts it, it is science that should be rejected.

The Independence category is a pacifying position which sees religion and science as separate entities who need not be in conflict. They are each in their own independent and watertight spheres, using different languages, having different functions, asking different questions, and using different methods of inquiry. According to its proponents, science would deal with the "objective and impersonal," religion with the "personal and subjective" (Barbour 2004, 32). The late Stephen Jay Gould is one of its most famous defenders, presenting in his Rocks of Ages the concept of NOMA-Non-Overlapping Magisteria. Science and religion would be two separate magisteria: "domains of reaching authority," not interfering with each other. "To cite old clichés," Gould famously wrote, "science gets the age of rocks, and religion the rock of ages; science studies how the heavens go, religion how to go to heaven" (Gould 1999, 12). For Gould, no conflict should exist between the science of evolution and creation, for evolution deals with the changes of species through time, and creation relates to the belief in God in relation to the origin of all things, which is completely compatible with science (Gould 1997).

Whereas Independence emphasizes the differences, the category of Dialogue holds that science and religion have something to say to each other that can be mutually enriching. Its defenders seek to find similarities between the fields in presuppositions, methods, and even in some concepts. Barbour argues that fruitful dialogue may emerge in "boundary questions," when science "clears the room" for questions that it cannot itself answer, such as "what was there before the Big Bang?" or the "mind/body" problem (Barbour 2004, 41). Proponents of Dialogue have no problem accepting the findings of science, but argue that science isn't enough to achieve a full grasp on reality, and religion can be a good and useful conversation partner.

The fourth category that Barbour identifies is what he calls Integration, which seeks to go a step further than Dialogue. Integration alternatives aim at "finding an elevated degree of conceptual unity" that mere Dialogue does not offer (Barbour 2004, 43). He identifies three candidate schools for this task: natural theology, theologies of nature, and "systematic synthesis." The old natural theology of the seventeenth and eighteenth centuries is considered an attempt at Integration insofar as it tries to find (or "prove") God through signs in nature, an effort that has reappeared in the modern clothing of the Intelligent Design movement. Theologies of nature go in the contrary direction, coming from a position of faith and looking for some form of resonance between the picture of the world revealed by religion and that which is revealed by science. However, Barbour himself favors what he calls systematic synthesis, which is an attempt to find a 
philosophical alternative that successfully encompasses an interpretation of reality coherent with both science and religion. To accomplish this task, Barbour suggests as a strong candidate Alfred North Whitehead's (18611947) process philosophy, which was elaborated under the influence of both scientific and theological ideas, and is considered a conceptual bridge for the debate among religion, science, and philosophy.

We are well aware of the criticisms and limitations of Barbour's fourfold typology, some of them pinpointed by Taede Smedes (2008). However, we believe we have at least two good reasons for sticking to it in our analysis. First, Barbour offers a simple but effective framework of analysis that makes it somewhat easy to promptly identify teachers' positions based on the type of data we have obtained from our research questions. Teachers' answers, as we shall see, were not nuanced (they were obtained from a multiple-choice questionnaire). Therefore, Barbour's categorization, although limited, seems to be the best choice for analysis, given the limited data. Moreover, Barbour himself recognizes that "any typology is a way of seeking broad patterns in comparing ideas" and that "such generalities (and exceptions to them) must of course be supported by detailed studies of particular people in particular religious traditions writing about specific sciences in specific historical contexts" (Barbour 2008, 265), which is close to what we are trying to do here. Second, Barbour's typology is still very much unknown in Latin America. The field of science and religion as a formal research area is still in its infancy, and Latin American researchers that usually spend time on these issues are from other fields of the humanities, barely knowing the work of Barbour and other well-known science-religion scholars. Thus, Barbour deserves at least to be introduced and considered in Latin American academia before we can move on to more nuanced and historically considered views.

\section{METHODS}

In this study, we used a questionnaire from a European project entitled BIOHEAD-CITIZEN (Carvalho and Clément 2007; Carvalho et al. 2008). This research project has been conducted in nineteen countries in Europe, Africa, and the Middle East. It sought to understand the interaction between social contexts and conceptions of biology teachers on controversial topics like evolution and the origin of life, health and sex education, environmental education, and gender equality, among others. The BIOHEAD-CITIZEN project is anchored on the theoretical background of the KVP model proposed by Clément (2006), which sees the conceptions of the actors of the educational system as emerging from interactions between three poles: $\mathrm{K}$ for knowledge, $\mathrm{V}$ for values, and $\mathrm{P}$ for practices. Many issues currently dealt with by science and biology teachers at the school level can be analyzed using this model, and preliminary results 
showed they vary from one country to another. This suggests that values and practices shared by local groups may play an important role in the conceptions of teachers regarding many issues, even though the knowledge (stemming from mainstream scientific literature) is supposedly the same for all countries (Carvalho and Clément 2007).

The size and variety of the BIOHEAD-CITIZEN survey questions allowed for investigation of a large number of matters related to conceptions of biology teachers in the surveyed countries, including the issue of the origin of life on Earth worked out in this study. Having been used in several countries, the application of this instrument enables the creation of a database to be used in future comparative studies. However, it is important to note that the questionnaire from the project used here has not been specifically designed to assess issues of evolution and the origin of life only. Some of the questions are indeed clearly related to this so-called "origins debate," and these are the ones we focused on. There are questions that explicitly deal with the issues at stake here: evolution, creationism, Intelligent Design, Adam and Eve, and so on. However, for this article we are focusing on only one of these questions, the one we found to be the most revealing, which deals specifically with the origin of life. Interviews were also carried out during the application of the questionnaire, and participants were asked to identify themselves with regard to religious affiliation. The full report of this study can be found in Silva (2015).

Data collection for the study followed an adaptation of the original design protocol, which was composed of at least six samples of fifty teachers by country (preservice and in-service teachers of biology and of language in primary schools). In this study the sampling was limited to in-service biology teachers. The criteria for inclusion were as follows: teachers graduated in biological sciences, acting in secondary school of their country (Argentina, Brazil, or Uruguay), and having already taught the topic of biological evolution and the origin of life. The cities chosen were Buenos Aires (Argentina, $N=50$ ), Belo Horizonte (Brazil, $N=62$ ), and Montevideo (Uruguay, $N=57$ ), following locations of the researchers involved in the study.

Our focus question was question A64 of the BIOHEAD-CITIZEN Questionnare: "Which of the following four statements do you agree with the most? Tick only one of the four statements":

(1) It is certain that the origin of life resulted from natural phenomena;

(2) The origin of life may be explained by natural phenomena without considering the hypothesis that God created life;

(3) The origin of life may be explained by natural phenomena that are governed by God;

(4) It is certain that God created life. 
Teachers could have great doubts in selecting the alternatives, for they may agree with more than one, or none, depending on their perception of how divine action actually takes place in the natural world, as we shall discuss in a moment. But the question asked them to choose the statement they agree with the most, so they had to make a choice that may have been somewhat uncomfortable.

It's also important to note that the survey question we are focusing on for this study deals specifically with the subject of the origin of life, even though some conclusions we draw from it may apply to an understanding of how these surveyed teachers see the issue of evolution and creation, or science and religion in general. Other questions in the full study report (Silva 2015) deal more specifically with Intelligent Design and evolution, and even directly with the evolution of humans. We are aware that all these subjects are separate issues and should not be conflated, as sometimes happens in popular understandings of these matters. Moreover, thinking that God may have intervened at some critical points, such as the transition from inorganic chemistry to organic (the core of the origin of life issue), or in the appearance of some specific biological structures, doesn't preclude acceptance of evolution (Behe 1996; 2008)—although these notions are widely rejected by the scientific community and legal rulings have been made against their teaching in the United States (Ayala 2016). However, we believe the question is still valid insofar as its redaction provides a general idea of how God could or could not be involved in biological processes, be they the evolution after the first cell arose or the appearance of the first living unit susceptible to evolution by natural selection. Besides, given that the target group of the survey were in-service biology teachers, we would expect that they would be able to differentiate between the origin of life problem and evolution in general. However, it would be normal, in a question such as this, for teachers to choose an alternative that generally describes how they see the issue of evolution and creation, even though this wasn't the specific target of the question.

The data obtained were tabulated and transformed into graphics, and statistical analysis was carried out for comparisons between countries using the Kruskal Wallis test and the Mann-Whitney test for differences between pairs of countries. After the results were tabulated, we interpreted them with regard to Barbour's four categories to relate science and religion.

We should highlight that the questionnaire was not created to test Barbour's categories. As we mentioned, it was created for a much more comprehensive study and we simply took advantage of it for practical reasons and for possible future studies in comparison with a large number of countries. Therefore, the results we found with respect to placing them in Barbour's categories could be considered preliminary and will require further study in the future. 
In analyzing the alternative answers to the four choices in our research question it is clear that a progression could be seen in the involvement of God with the origin of life issue. Therefore, in general terms, we identified Barbour's categories progressively, with the extremes being identified with the category of Conflict (alternatives 1 and 4) and the middle ones with more Dialogue-Integration points of view.

Therefore, we considered alternative answer (1) "It is certain that the origin of life resulted from natural phenomena" as an evolutionary view that may suggest the adoption of Barbour's Conflict view or even Independence. Option (2) "The origin of life may be explained by natural phenomena without considering the hypothesis that God created life" can also be considered evolutionist, however it may suggest that the person separates God's activity in nature from his or her personal faith, which could be linked to the categories of Independence or Dialogue. Answer (3) "The origin of life may be explained by natural phenomena that are governed by God" is clearly an Integrationist view, very much like Theodosius Dobzhansky's position, who, in his famous article "Nothing in Biology Makes Sense except in Light of Evolution" (1973), wrote: "I am a creationist and an evolutionist. Evolution is God's, or Nature's, method of Creation" (127). Finally, alternative (4) "It is certain that God created life" would mean, given this set of options, a view that rejects evolution in favor of a creationist view, also indicating a Conflict position in Barbour's terms.

\section{RESULTS AND DISCUSSION}

The comparison of Argentina, Brazil and Uruguay samples showed distinct patterns in each country (Figure 1). The answers of Brazilian teachers were the ones most linked to religious affiliation; none of the Argentinian teachers assigned exclusively to God the origin of life (alternative 4). Uruguayan teachers, the country with the most consolidated secularism of the three, were more incisive in their certainty of natural origin of life.

Statistical analysis by the Kruskal-Wallis test showed very significant differences between the answers to the question by the three country samples $(M=28.13 ; p<.00001)$. When these differences were analyzed between pairs of countries, the Mann-Whitney test showed a significant difference between Brazil and Uruguay $(Z=4.41 ; p=.00001)$ as well as between Brazil and Argentina $(Z=4.49 ; p=.000007)$. In contrast, there was no significant difference between Argentina and Uruguay $(Z=-0.81$; $p=.420)$.

When we analyze teachers' answers in light of Barbour's categories, results suggest that the answers of Argentinian and Uruguayan teachers are closer to the Independence category than to the Conflict category, because most teachers of these countries declared themselves followers of a religious belief (Figure 2). However, about 80 percent selected the 
clearly evolutionist items 1 or 2 . No one in Argentina and only four percent in Uruguay ticked the clearly creationist item 4. It could be said, therefore, that the conceptions of Argentinian and Uruguayan teachers are in agreement with Gould's NOMA (1997; 1999). The results obtained in these two countries are similar to some of those obtained, using the same

\section{A64. Which of the following four statements do you agree with the most? (\%)}

\section{It is certain that God created life.}

The origin of life may be explained by natural phenomena that are governed by God.

The origin of life may be explained by natural phenomena without considering the...

It is certain that the origin of life resulted from natural phenomena.

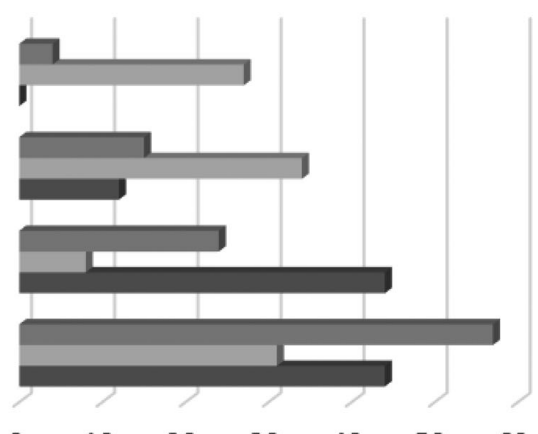

\section{@ Uruguay Brazil @ Argentina}

Figure 1. Percentages of answers to question A64 "Which of the following four statements do you agree with the most?" by biology teachers from Argentina, Brazil and Uruguay. Very significant differences $(p<.0001)$ were found between the three samples. (Source: Survey data).

Teachers' religions by country (\%).

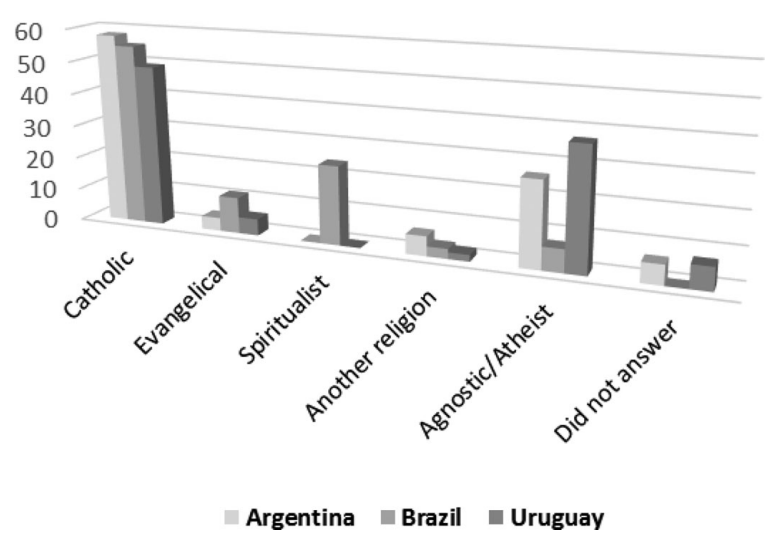

Figure 2. Percentage of religious affiliation declared by the teachers surveyed in the three countries. (Source: Survey data). 
questionnaire, in several countries by Clément (2008; 2015a), Clément and Quessada (2008), and Carvalho et al. (2012).

It is important to highlight that the classification given to Argentinian and Uruguayan teachers in the Independence category is based on the high percentage of teachers who claim to be religious (Figure 2) and who nevertheless ticked the items more related to an evolutionary view. The Independence category is often seen as a way to avoid conflict, and its approach was famously used by the theologian Langdon Gilkey (19192004) in the notorious Arkansas Trial in 1981 (Gilkey 1985). Teachers who feel serious about their religious commitment but don't see a necessary conflict between science and religion often use this approach, as was revealed by some of the interviews carried out while doing this study (Silva 2015). These interviews confirmed that secondary school teachers in both Argentina and Uruguay consider religious issues as personal and intimate matters, letting the school deal with the scientific approach concerning the teaching of biological sciences, particularly evolution. As one Uruguayan teacher noted, demonstrating the separation between the two fields as seen by students (Silva 2015, 164): "In general I do not believe [that problems about students' religion occur]. When we speak about theories of origin of life and I ask if there is someone [among the students] who professes a religion and wants to comment on anything, no difficulty arises." This very same situation of separation between fields is also brought by many of the teachers themselves, as exemplified by the speech of another Uruguayan teacher (Silva 2015, 165): "I think that, even being a Catholic, my vision is that one can believe in God on the side of spirituality without contradicting my scientific part."

However, we did not observe the same scenario with Brazilian teachers. Only 39 percent of them ticked the evolutionist items 1 (31 percent) or 2 (8 percent), and 27 percent ticked the most creationist-oriented item 4, and 34 percent the item 3, 4 being at the same time creationist and evolutionist (Figure 1). This last group of Brazilian biology teachers merge their scientific knowledge with their religious convictions, thus aligning with the Integration or in the Dialogue category of Barbour. Exactly how these teachers do this type of integration would require further study, and suggestions have been widely discussed in theistic evolutionist (or evolutionary creationist) circles such as the Biologos Foundation and in numerous publications (Collins 2006 and Alexander 2008, to name two well-known examples).

Moreover, these results are interesting if compared to the Datafolha survey we mentioned earlier (which in fact is the Brazilian version of the long standing Gallup Poll with regard to origins; see Newport 2014). For the general public, the percentage of integrationists rises to 59 percent, while in our sample of teachers it is only 34 percent, which may mean that teachers tend to be more trapped in the Conflict thesis, feeling a stronger 


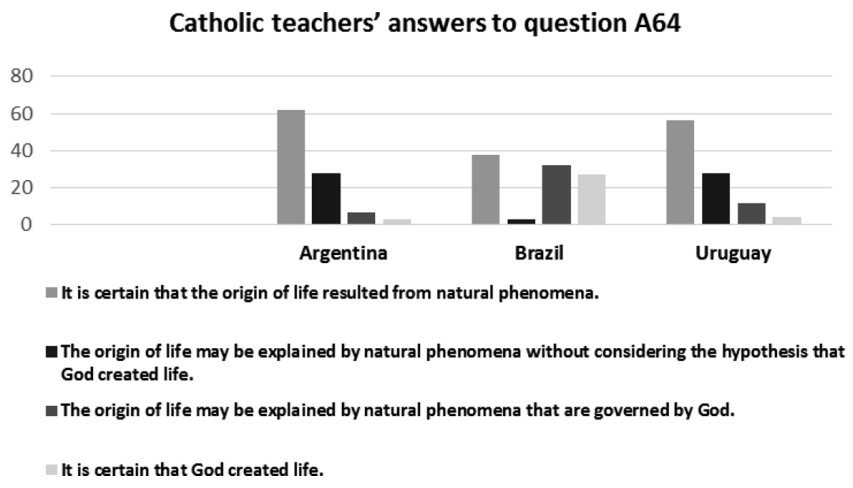

Figure 3. Answers of Catholic teachers of the three countries to question A64. (Source: Survey data).

pressure to either reject a theistic view because of the science of evolution or to reject science in favor of what would be considered a more "Christian position," in this case some form of creationism. In fact, 31 percent of Brazilian teachers ticked the clearly creationist item 4 (Figure 1), which means that we have the same percentage of "atheistic" evolutionists (option 1) and antievolution creationists (option 4). This strongly suggests that 62 percent of biology teachers in Brazil believe religion and science are in conflict and an option needs to be made when it comes to who has the final word on the question of origins.

With regard to adherents of option 4, the more creationist one, they include the evangelical Protestant teachers ( 11 percent, Figure 2), but also about one-third of the Catholic teachers (Figure 3). This has been extensively documented in the literature: evangelicals are definitely more inclined toward creationist and antievolutionist positions than other religious denominations (see El-Hani and Sepulveda 2010, in their study with evangelical students, for example).

Similar results to what we have found were documented by Caldeira, Araujo, and Simões (2012) in their research comparing Brazilian teachers with Portuguese ones, showing that the former were more inclined to hold religious views about the origin and evolution of life than the latter. These authors also concluded that the Brazilian teachers are somewhat able to reconcile the two fields of knowledge (scientific and religious), but questioned whether such compatibility could preclude or harm the teaching of biological evolution. Silva et al. (2014) showed that future biology teachers still in training in universities begin with conceptions closer to creationism and tend to accommodate the evolutionary scientific view in the course of their studies. Porto and Falcão (2010), however, showed that Brazilian biology teachers have less influence on their students' conceptions about the origin of biodiversity than family culture and traditional religious 
authorities. Indeed, Meyer and El-Hani (2013) reinforce this finding, stating that, when evolutionary views are confronted with creationist ideas, it is very unlikely that any debate-based interactions will arise (and the authors define "debate" as a minimum willingness to hear two or more sides and eventually, if convinced, change opinion). There is a tendency for students to deny and block the scientific understanding about the origin of life and evolution when it is perceived that such ideas directly conflict with views that arise from religious commitments. Furthermore, Nicolini, Falcão, and Silva Faria (2010) argue that Brazilian teachers should have full access to the theoretical aspects related to scientific knowledge about the origin of life, so that they could prepare their teaching on the topic grounded in adequate knowledge of the nature of science as it relates to religious interferences that may arise.

We are aware that conceptualizations about the relationship between science and religion are much more complex than merely assigning categories based on a single answer to a small set of questions, or just one. Coutinho et al. (2014), for example, have aptly demonstrated that conceptualizations can transit from one category to another, or involve no traceable categories at all. However, we still believe this generalization to be useful as an initial step for further transnational comparative studies in the area of science and religion.

The combination of lack of knowledge or adequate preparation to teach such topics results in the fusion of scientific ideas and religious ones, as illustrated by this recorded speech from a Brazilian teacher (Silva 2015, 224): "I asked students: who directed evolution? It was something bigger, who was this something bigger? It was God." The results found by Carvalho et al. (2012) may confirm these findings; these authors indicate that the Brazilian teachers seem to live with creationist views and evolutionary ones without a perception of conflict. But it is questionable whether this absence of conflict may be related to a poor understanding of the science or a fragile commitment to a religious tradition. The same study also shows strong religious influences on the conceptions of Brazilian teachers.

The type of data we obtained could help explain some of the reasons why Brazilian students score so poorly in international evaluations of science such as PISA (Waltenberg 2005). Because evolution is considered the most important topic to understand the relationships and dynamics in the biological world (Ayala 2016), teachers that do not have an adequate grasp on the fundamental aspects of the theory may negatively impact students' learning of biology and science. Forrest and Gross (2007) suggest that it is crucial to adequately prepare undergraduate students of science and biology that will become teachers, as to avoid distortions of basic scientific concepts. The discussion of biology and science curricula in the formation of future teachers is of fundamental importance for a country to improve 
its scientific literacy, and should involve not only the government, but society in general and the scientific community.

The possible influence of different church-state relationships among the three countries on the teachers' conceptions of origins that we had proposed as a hypothesis was not revealed as consistent in the present study. The country initially considered as less secular, Argentina (with its openly Catholic constitution) presented percentages of responses similar to those in the country with more consolidated secularism, Uruguay. On the other hand, the responses of Brazilian teachers suggest that religion seems to have significant influence on teachers' conceptions about the origin of life and evolution, confirming what is perceived by authors like Cunha (2009) that Brazil is far from being a secular or lay state in practice and that religious influence is present in various spheres of society. As mentioned earlier, Brazilian teachers were the ones who presented answers most linked to religious commitment. None of the Argentinian teachers assigned exclusively to God the origin of life, while Uruguayan teachers showed sharp tendencies towards a purely naturalistic origin of life, with very few teachers attributing to God alone the origin of life (Figure 1). Brazilian teachers leaned most strongly toward the purely religious option 4; they also included the fewest atheists and had the highest percentage of evangelicals in comparison to the other countries (Figure 2). Oliveira (2009), as well as El-Hani and Sepulveda (2010), have noted that evangelical students in Brazil find it difficult to reconcile the fields of science and religion, which could mean that this difficulty also occurs among teachers of the same religious belief.

Although most teachers in the three countries declared themselves religious, and among these mostly Catholic, there were differences in relation to other data on religiosity. Among the Argentinian and Uruguayan teachers there many atheists and agnostics, whereas among Brazilians their number was negligible (Figure 2). The number of evangelical teachers was substantially higher among Brazilians. Considering these data, it can be inferred that this religious pattern could influence the views of teachers, given that evangelicals are more refractory to scientific knowledge about evolution than Catholics tend to be (Madeira 2007; Silva 2015). Several studies already mentioned here indicate difficulties of evangelical students of biological sciences in accommodating scientific knowledge into their religious background (Sepulveda and El-Hani 2003; El-Hani and Sepulveda 2010; Silva et al. 2014). However, we must be cautious with conclusions regarding the influence of religion on the teachers' answers, because only a minority of teachers, even in Brazil, declared themselves as evangelicals, and of course local contexts and many other factors could influence teachers' answers in studies like this one.

The two main differences of Brazilians, compared to Argentinians and Uruguayans, are the high percentage of spiritualists (24 percent) compared 
to 0 percent in the other two countries and the low percentage of agnostics or atheists (7 percent) compared to 26 percent and 37 percent in Argentina and Uruguay, respectively (Figure 2). This can explain the different pattern of Brazilian teachers' answers, which were significantly more linked to religion than to the science of evolution. In Brazil, spiritualist religion is often linked to biological evolution in mystical narratives that can be often seen in popular publications in street newsstands, and this could be an interesting line of research for future studies.

As we can see from Figure 2, the majority of teachers of the three countries were Roman Catholic. Figure 3 shows the proportion of the Catholic teachers' answers to the research question A64. A chi-square test showed that there are statistically significant differences between the answers of the Catholic Brazilian teachers and the Catholics from the other countries. Importantly, among the Brazilians, the pattern of different answers presented by the group as a whole has remained. Therefore, the differences in responses between Brazilian teachers and the teachers of the other two countries are not explained merely by the teachers' religion, because even though they profess the same Catholic faith, teachers' conceptions varied depending on their country of origin. These important differences among countries, with teachers who declare to have the same religion showing different conceptions, have already been shown in other continents other than South America (Clément 2015b). They are clearly related to several national sociocultural factors. One of them can be the poor training of the Brazilian teachers on the origin of life (Coimbra and Juliana Silva 2007), among many possible others.

Other studies that have applied the BIOHEAD-CITIZEN Questionnaire in different countries have reported that a limitation in thinking about the nature of science in the classroom is possibly related to poor scientific instruction on the origin of life and related subjects in teacher training and formation courses (Quessada, Munoz, and Clément 2007; Clément and Quessada 2008). This is definitely true in Brazil, as also pointed by Andrea Cerqueira (2009), who conducted a study about the formation of science and biology teachers in Brazil. The specific theme of the chemical origin of life is not a mandatory course in the curricula of biological sciences majors around the country, which can explain the deficiencies in teaching of this particular topic (Nicolini et al. 2010).

Finally, our results are consistent with Clément's KVP model mentioned earlier: teachers' conceptions on the origin of life and evolution clearly emerge from the interactions between their scientific knowledge $(\mathrm{K})$, their values $(\mathrm{V})$, and their social practices $(\mathrm{P})$, which are linked to their religion and their national culture. The important differences among countries can also be interpreted using the concept of "geography of reading" from Livingstone (2010). If we bear in mind the following factors-(1) 
Argentina with its society influenced by governments of varying ideological orientation and the recent choice of an Argentinian pope (Lowney 2013), in addition to a whole set of recent changes in its society in relation to the spectrum of religiosity and its influence on society (Valenzuela, Scully, and Somma 2009); (2) Uruguay with its strong secularization and recent progressivist policies (Jover-Cirillo 2010); and (3) Brazil with its changing religiosity (Silva and Mortimer, 2014) — it becomes clear that the social and religious conditions of each country can provide an interesting field for future analyses based on "geography of reading" as proposed by Livingstone (2010).

\section{CONCLUSIONS}

In summary, the secular government factor showed less impact than expected in teachers' conceptions about the origin of life on Earth, although this secularism is not clearly present in Brazilian society. Separation between science and religion was evident in the answers of both Argentinian and Uruguayan teachers. For most of them, the origin of life may be explained by natural phenomena, which doesn't necessarily preclude belief in God. The pattern of a large part of Brazilian teachers' conceptions about the origin of life was shown to be different from teachers in Argentina and Uruguay, as a large part of them showed conceptions based on religious views about how life originated on Earth. This difference is also observed when comparing only Catholic teachers of these three countries. Therefore, the influence of religion is not the same in Brazil, where there are more evangelical teachers, but also where Catholic teachers are more creationist than their Catholic colleagues in Uruguay and Argentina. The influence of each national sociocultural context needs to be further analyzed.

How these teachers' conceptions manifest in actual classroom teaching is also a matter of further investigation. We believe that there needs to be a rethinking in the training of science and biology teachers in the Brazilian educational system, especially with respect to the scientific view on the origin of life and evolution, so that effective teaching of these subjects may take place. As previously proposed by Nicolini et al. (2010), the present study confirms the need for biology teachers to have the widest possible access to the fundamental theoretical aspects about the origin of life and how it relates to the nature of the construction of scientific knowledge through inquiring, making and testing hypotheses, and creating models. Besides, teacher training must also be a matter of further study in order to analyze the possibilities of including the study of the relations between science and religion, so that teachers may see that conflict is not the only option and that independence and dialogue between the fields are viable options other than mere warfare. 


\section{ACKNOWLEDGMENTS}

We kindly thank the project "Science, Philosophy and Theology in Latin America" held at the University of Oxford's Ian Ramsey Centre for Science and Religion (IRC), which through the workshop "The Origin and Concept of Life" at the Galapagos Islands provided the opportunity for contact with Professor Emeritus John Hedley Brooke, who gave precious suggestions and insight for this article.

\section{NoTE}

1. PL8099/2014, November 13, 2014, "It is inserted in the curriculum of the Public and Private Networks of Education, contents on Creationism." Retrieved from http://www.camara.gov.br/proposicoesWeb/fichadetramitacao?idProposicao $=777616$

\section{REFERENCES}

Alexander, Denis. 2008. Creation or Evolution: Do We Have to Choose? Oxford, UK: Monarch. Ayala, Francisco J. 2016. "Scientific Literacy and the Teaching of Evolution." Ludus Vitalis 21:231-37.

Barbour, Ian G. 1990. Religion in an Age of Science. San Francisco, CA: Harper.

- 2004. When Science Meets Religion: Enemies, Strangers, or Partners? San Francisco, CA: Harper.

2004. Quando a ciência encontra a religiāo: Inimigas, Estranhas ou Parceiras? Translated by Paulo Salles. São Paulo, Brazil: Ed. Cultrix.

—. 2008. "Taking Science Seriously without Scientism: A Response to Taede Smedes." Zygon: Journal of Religion and Science 43:259-69.

BBC News. 2009. "Darwin Teaching 'Divides Opinion'." Available at http://news.bbc.co. uk/2/hi/uk_news/education/8322781.stm

Behe, Michael. 1996. Darwin's Black Box: The Biochemical Challenge to Evolution. New York, NY: Free Press.

2008. The Edge of Evolution: The Search for the Limits of Darwinism. New York, NY: Free Press.

Brooke, John Hedley. 1991. Science and Religion: Some Historical Perspectives. Cambridge, UK: Cambridge University Press.

Brum, Eliane. 2005. "E no princípio era o que mesmo?" Época: 346. Available at http://revistaepoca.globo.com/Epoca/0,6993,EPT884203-1664-1,00.html

Caldeira, Ana Maria de Andrade, Elaine Araujo, and Graça Simões. 2012. "Creationism and Evolution of Brazilian Teachers and Teachers-to-Be." Journal of Life Sciences 6:1,99-109.

Carvalho, Graça Simōes, and Pierre Clément. 2007. "Projecto 'Educação em Biologia, Educação para a Saúde e Educação Ambiental para uma melhor cidadania’: Análise de manuais escolares e concepçôes de professores de 19 países (europeus, africanos e do próximo oriente)." Revista Brasileira de Pesquisa em Educação em Ciências 7:1-21.

Carvalho, Graça, Pierre Clément, Franz Bogner, and Silvia Caravita. 2008. BIOHEADCITIZEN: Biology, Health and Environmental Education for Better Citizenship, Final Report. Brussels, Belgium: FP6 7. Available at http://cordis.europa.eu/ result/rcn/47881_en.html

Carvalho, Graça Simões, Rosa Branca, Paloma Silva, Elaine Araujo, and Ana Maria Caldeira. 2012. "The Influence of Religion on Portuguese and Brazilian Teachers' Conceptions about the Origin of Life." In Proceedings of the ESERA 2011 Conference - Science Learning and Citizenship. Part 11: Cultural, Social and Gender Issues, edited by Catherine Bruguière, Andreé Tiberghien, and Pierre Clément, 6-11. Braga, Portugal: European Science Education Research Association.

Censo, IBGE. 2010. "Censo Demográfico 2010: Características gerais da população, religião e pessoas com deficiência." Available at http://www.ibge.gov.br 
Cerqueira, Andrea Vianna. 2009. Representaçôes sociais de dois grupos de professores de biologia sobre o ensino de Origem da Vida e Evolução Biológica: Aspiraçôes, ambiguidades e demandas profissionais. Dissertação. Masters Dissertation, Universidade Federal do Rio de Janeiro, Brazil.

Clément, Pierre. 2006. "Didactic Transposition and the KVP Model: Conceptions as Interactions between Scientific Knowledge, Values and Social Practices." Proceedings of ESERA Summer School 2006, 9-18.

. 2008. "Human Evolution: Objectives, Methodologies, Main Achievements and Implications." In BIOHEAD-CITIZEN: Biology, Health and Environmental Education for better Citizenship, Final Report. Brussels, Belgium: FP6. Available at http://cordis.europa.eu/result/rcn/47881_en.html

. 2015a. "Creationism, Science and Religion: A Survey of Teachers Conceptions in 30 Countries." Procedia-Social and Behavioral Sciences 167:279-87.

. 2015b. "Muslim Teachers' Conceptions of Evolution in Several Countries." Public Understanding of Science 24:400-21.

Clément, Pierre, and Marie Pierre Quessada. 2008. "Les convictions créationnistes et/ou évolutionnistes d'enseignants de biologie : Une étude comparative dans 19 pays." Natures Sciences Sociétés 16:154-58.

Coimbra, Lipp Roberta, and Juliana Silva. 2007. "Ensino de evolução biológica e a necessidade de formação continuada." In Atas do VI Encontro Nacional de Pesquisa em Educação em Ciências. Florianópolis, Brazil: Abrapec.

Collins, Francis S. 2006. The Language of God: A Scientist Presents Evidence for Belief. New York, NY: Free Press.

Coutinho, Francisco, Danusa Quessada, Fernanda de Jesus, Raquel Winter, and Gabriel Menezes Viana. 2014. "Sobre as relaçōes entre ciência e religião e alguns apontamentos para uma agenda de pesquisas em educação em ciências." In Atas do VIII ENPEC - Encontro Nacional de Pesquisa em Ciências - I CEIC - Congreso Internacional de Investigación en Enseñanza de las Ciencias.

Cunha, Luiz Antônio. 2009. "A Luta Pela Ética No Ensino Fundamental: Religiosa Ou Laica." Cadernos de Pesquisa 39:401-19.

Datafolha Instituto de Pesquisas. 2010. "59 percent acreditam na evolução entre as espécies, sob o comando de Deus." Available at http://datafolha.folha.uol.com.br/opiniaopublica/ 2010/04/1223573-59-acreditam-na-evolucao-entre-as-especies-sob-o-comando-dedeus.shtml

Dobzhansky, Theodosius. 1973. "Nothing in Biology Makes Sense Except in Light of Evolution." American Biology Teacher 35:125-29.

El-Hani, Charbel Niño, and Claudia Sepulveda. 2010. "The Relationship between Science and Religion in the Education of Protestant Biology Preservice Teachers in a Brazilian University." Cultural Studies of Science Education 5:103-25.

Engler, Steven. 2007. "Tipos de criacionismos cristãos." Revista de Estudos da Religiāo 7:83-107.

Esquivel, Juan Cruz. 2003. "Igreja Católica e Estado na Argentina e no Brasil. Notas Introdutórias para uma Análise Comparativa." Ciencias Sociales y Religión/Ciências Sociais e Religiāo 5(5):191-223.

Fernandes, Nelito. 2009. "Metade do Brasil será evangélica?" Época Available at <https://glo.bo/2oeaEDH>. Accessed on: 18 March 2017.

Forrest, Barbara, and Paul R. Gross. 2007. Creationism's Trojan Horse: The Wedge of Intelligent Design. Oxford, UK: Oxford University Press.

Garros, Tiago Valentim. 2014a. "Ciência e religião em perspectiva: Inimigas mortais ou amizade a ser (re)descoberta?" In Proceedings of 27th Congress of SOTER, 548-62.

. 2014b. O Movimento Criacionista e Sua Hermenêutica: possibilidades de diálogo entre a teologia e a ciência evolucionista. Masters Dissertation, Faculdades EST, São Leopoldo, Brazil.

Gilkey, Langdon B. 1985. Creationism on Trial: Evolution and God at Little Rock. Minneapolis, MN: Winston Press.

Gould, Stephen Jay. 1997. “Non-Overlapping Magisteria.” Skeptical Inquirer 106:16-22.

. 1999. Rocks of Ages: Science and Religion in the Fullness of Life. New York, NY: Ballantine.

Harrison, Peter. 2015. The Territories of Science and Religion. Chicago, IL: University of Chicago Press. 
Jover-Cirillo, Silvina. 2010. "Influence of Religious Institutions in the Creation and Implementation of Public Policy: The Case of Roman Catholic Argentina and Secular Uruguay." Global Affairs 5. Available at http://digitalcommons.du.edu/ucol_gs/5

Livingstone, David Noel. 2010. Putting Science in Its Place: Geographies of Scientific Knowledge. Chicago, IL: University of Chicago Press.

Lowney, C. 2013. Pope Francis: Why He Leads the Way He Leads. Chicago, IL: Loyola Press.

Madeira, Andréa. 2007. Fé e evolução: A influência de crenças religiosas sobre a criação do homem na aprendizagem da teoria da evolução com alunos do $3^{\circ}$ ano do ensino médio. PhD Dissertation, PUC/SP, São Paulo, Brazil.

Meyer, Diogo, and Charbel Niño El-Hani. 2013. "What Is at Stake in the Confrontation between Creationism and Evolution?" Filosofia e História da Biologia 8:211-22.

Newport, Frank. 2014. "In U.S., 42\% Believe Creationist View of Human Origins.” Available at http://www.gallup.com/poll/170822/believe-creationist-view-human-origins.aspx

Nicolini, Livia Baptista, Eliane Falcão, and Flavio Silva Faria. 2010. "Life's Origin: How Do Pre-Service Biology Teachers Deal with this Subject?" Ciência \& Educação 16:355-67.

Oliveira, Graciela da Silva. 2009. Aceitaçãolrejeição da Evolução Biológica: Atitudes de alunos da Educação Básica, Masters Dissertation, Universidade de São Paulo, São Paulo, Brazil.

Oro, Ari Pedro. 2008. Religião, Coesão Social e Sistema Político na América Latina. São Paulo, Brazil: Instituto Fernando Henrique Cardoso.

Porto, Paulo Roberto de Araújo, and Eliane Falcão. 2010. "Teorias da origem e evolução da vida: Dilemas e desafios no ensino médio." Ensaio Pesquisa em Educação em Ciências 12:13.

Quessada, Marie-Pierre, François Munoz, and Pierre Clément. 2007. Les conceptions surl'évolution biologique d'enseignants du primaire et du secondaire de douze pays (Afrique, Europe et Moyen Orient) varient selon leur niveau d'étude. Strasbourg, France: Actes Colloque AREF (Actualité de la Recherche en Education et en Formation). Available at https://halshs.archivesouvertes.fr/hal-01026095/document

Rodrigues, Wellington Gil, and Rosilene Motta. 2011. "Relações entre Ciência e Religião na Perspectiva dos Professores da Faculdade Adventista de Fisioterapia (FAFIS).” Práxis Teológica 11 (1). Available at http://www.seer-adventista.com.br/ojs/index.php/praxis/issue/archive

Sepulveda, Claudia, and Charbel Nino El-Hani, 2003. "A relação entre religião e ciência na trajetória profissional de alunos protestantes da Licenciatura em Ciências Biológicas." In Atas do IV Encontro Nacional de Pesquisa em Educação em Ciências (ENPEC). Bauru, Brazil: ABRAPEC.

Silva, Heslley Machado. 2015. Professores de Biologia e Ensino de Evolução: Uma perspectiva comparativa em países com contraste de relação entre Estado e Igreja na América Latina. $\mathrm{PhD}$ Dissertation UFMG, Belo Horizonte, Brazil.

Silva, Heslley Machado, Elaine Araújo, Daiana Gibram, and Graça Carvalho. 2014. "Conceptual Change about Evolution and Origins of Life throughout an Undergraduate Course of Biological Sciences." In Proceedings of INTCESS 14 - International Conference on Education and Social Science Proceedings, 1249-58.

Silva, Heslley Machado, and Eduardo Mortimer. 2014. "Rescuing Darwin Brazil". In Latin American Perspectives on Science and Religion, edited by Ignacio Silva. London, UK: Pickering \& Chatto.

Silva, Kátia Adriano Matias da, and Sílvia Fontenele. 2007. "O laicismo no Uruguai." Ameríndia 4:1-8.

Smedes, Taede A. 2008. "Beyond Barbour or Back to Basics? The Future of Science-and-Religion and the Quest for Unity." Zygon: Journal of Religion and Science 43:235-58.

Valenzuela, Julio Samuel, Timothy Scully, and Nicolás Somma. 2009. "Social and Political Effects of Religiosity and Religious Identities in Latin America." Comparative Politics 40(1):1-20.

Waltenberg, Fabio D. 2005. "Ineqüidade educacional no Brasil: Uma avaliação com dados do PISA 2000.” Revista Economia 6(1):67-118. 